\title{
When Frederic Henry Is Disillusioned about His Identity: Alienation in $A$ Farewell to Arms: A CriticalAnalysis.
}

\author{
Akm Aminur Rashid \\ School of Language and Media Studies, Department of English, Dalarna University, Sweden
}

\begin{abstract}
The research concentrates the protagonist, Lieutenant Frederick Henry's exploring his identity. A critical observation undertaken here presents Frederick Henry's sense of alienation that drives him all through his life shapes the end accordingly. His is a character presented in A Farewell to Arms is found as being in disillusionment and nervous condition. The research finds his failure to live in his homeland, America. Seeking the purpose of his life, he joined the Italian armies in W.W.I but he also has to escape Italy after his illusion about the war fades away. Later he has an affair with a British nurse, Catherine Barkley; and finally decides to be a family man. He elopes with her to Switzerland and also leads a life of three months of happiness but unfortunately he could not change the fate. Catherine Barkley dies of hemorrhages. If it is scrutinized, Frederick Henry's ultimate identity dilemma was the real life experiences that taste quite pessimistic the novelist, Ernest Hemingway could ever encounter. So charged with distress that Frederick Henry's planted happiness subtly turns to darkness of alienation. Perhaps, the idea that a pen could penetrate realities was hidden in the aftermath of Frederick Henry's alienation.
\end{abstract}

Keywords: Disillusionment, War, Love, Death, Alienation

\section{Introduction}

In A Farewell to Arms, as the narrative unfolds, Ernest Hemingway delivers a plot of a battle as refered to First World War, and it's impact upon the civil world. The novel, most importantly, features a world of predicament for it's protagonist as refered to Lieutenant Fredeick Henry, an American, who although feels allied with the Italian army as an ambulance driver but does not necessarily derive pleasure from war. The storyline is a study of an American ambulance driver's disillusionment story, such as, his disillusionment about his 'being' and 'not being' an American; his disillusionment about trying of retaining the identity of lieutenant in the Italian front in First World War; and his disillusionment in his searching of love and making home with his beloved. Most significantly, the fact of his being disillusioned about his identity that the paper will critique is the key analytic discussion in the story as it narrates Frederic Henry as being a rootless man with having no family; and fixed identity. The author makes Frederic fight for his identity but the incredible intensity of Frederic's fighting ultimately fails; and he is then surrounded with the eminent threat of alienation.

\subsection{Previous Works}

In this section, the following reviews previously done have aimed at arguing 'alienation' in $A$ Farewell to Arms purely in terms of objectifying women, especially the character of Catherine; and exposing of female prostitutes for the soldiers' comfort; increasing gender hierarchy; inconstant psychology of the protagonist; and highlighting queer emotional behavior respectively. In contrast, this reaserch will endeavour to establish Frederic Henry's alienating persona as being the key representation of the storyline of the narrative. Notwithstanding that, the reviewing of literatures is as follows:

Simone de Beauvoir, a postwar voice, who although reads that Catherine Barkley is an anti-mythic character as represented; and extols Hemingway for "regard[ing] women as fellow creatures", in honor of making a female "without mystery" who are presented as being a "human being" (295), critic, like Jamie Barlowe-Kayes makes an unrelenting remonstration available for Hemingway's depicting alienation in the form of objectification of women while promoting to men's masochistic quality as this research observes.

Barlowe-Kayes puts forward a disagreeably concise abstract of Hemingway's handling of playing down his feminine characters:

Women are inspiration, muses, sexual temptation and release from sexual tension, they serve as nurturers, solvers of domestic problems and creators of conditions which allow men to go on accomplishing-and making decisions. Even Hemingway's ways of holding women in esteem marginalized them-kept them as objects, playthings and nurturers, allotting them no domestic power. (27)

Barlowe-Kayes believes that Hemingway in his novels presented woman as purely a commodity. The portrayal of young females as prostitutes in Gorizia for the Italian officers', and the soldiers' recreation from the monotonous war stands for the proof of Hemingway's chauvinistic characteristic. Besides, Frederic's approach 
towards Catherine Berkley with a seductive intension to seduce her; Catherine's being a blow up doll in the eyes of an onanistic persona like Frederic; and her unusual dying in child-birth also reflect on Hemingway's creation of Frederic's chauvinistic characteristic. Following A Farewell to Arms, Barlowe-Kayes, concerning Catherine Berkley, argues that "Berkley's position as a female character who dies bearing an unwanted child further underscores the denial of female subjectivity in this text" (31).

In fact, the concept of alienation from the Feminist perspective can be seen in the form of privileging men attributing subjectivity only to them and ignoring women attributing objectivity to them as Barlowe-Kayes ends up by saying that "thus, inside a shared, acknowledged, destabilized space our collective work as scholars and critics does not perpetuate the problematic implications of Hemingway's fictional and non-fictional work: that women are context, not text, and objects, not subjects" (33).

From studying some gender critics' analyses, this research observes alienation in A Farewell to Arms in terms of gender discrimination. According to Marc Hewson, "one of the implications of a "patriarchal culture...founded on sacrifice, crime, [and] war" is the need men often feel to prove themselves militarily to claim their masculine birthright. Hemingway's hero experiences this also, trying, early in the novel, to use his military status to define himself" (53). Hewson adds that "Unfortunately western culture has historically privileged masculinity at the expense of the feminine, creating a hierarchy of gender in which the masculine value is positive and the feminine negative" (52).

However, the term, alienation in A Farewell to Arms, this research observes, is further approached by Robert E. Gajdusek, who focuses on Frederic's mental conflict, and indecisive nature. As Frederic continuously meets Catherine but cannot decide if he really loves Catherine, Gajdusek compares Frederic's love as "opportunistic and willing to use Catherine's masturbatory need as a means to his own sexual fulfillment while she is also well aware of her willingness to the illusion of love as a hysterical mode of excitement" (26). Gajdusek also concentrates on Frederic's private discussion with the priest in the hospital. Gajdusek sees that the priest insists Frederic visits the Abruzzi, which the priest believes as being a holy place, but Frederic exposes his inability to go that place because he feels as if he had not decided. Hence, Gajdusek takes the chances to argue:

Frederic acknowledges distinctions-"There is a difference between the night and the day" -and he well knows the difference between the Abruzzi, where he did not go though he wanted to, and the centers of culture, where he nevertheless went for his sexual debauch. But in Milan, he underwent loss of identity and dissolution of the integral boundaries of the Self when he exposed himself to rapid repetitive cycles. (30)

Gajdusek's argument is that "the whirling world of Milan and the big cities, where distinctions between the self and the not self are lost is poised in the novel against the priest's world of Abruzzi" (29).

By Milan and big cities, Gajdusek indicates 'world of cycling enveloping darkness' and by Abruzzi, he indicates 'world of high clear paternal spiritual authority' (29). Decidedly, Gajdusek observes two contrasting views of love in the discussion between the priest and Frederic as the priest wants Frederic believes love is an internal imperative for soul's purification, and salvation, but Frederic takes the priest's defining of love as heresay; and chooses to visit the whores than that of paying attentions to the priest's psychologically abstract words such as love, divinity, and peace. As the priest keeps talking about the spritual essence of love, the captain says to Frederic, "come on". "We go whorehouse before it shuts" (9). Frederic agrees and then bids the priest good night. Frederic's opportunistic use of Catherine's masturbatory needs; and womanizing are, indeed, Frederic's alienation from understanding the real feeling of love that he has to realize at the end.

Following "A Queer Sensibility of A Farewell to Arms" as written by Debra A. Moddelmog, this research observes a context of alienation in Moddelmog's analysis of the homoerotic emotions between the characters of Frederic and of the priest; and of Catherine and of Ferguson respectively. Such homoerotic emotions among these characters clearly remark as alienation from heterosexuality. Moddelmog explores among these characters two kinds of sexual mores. In particular, "sex with prostitutes often while drunk, sex outside of marriage, sex in a hospital bed almost surely the woman on top" (9). Moddelmog also notes the homosexual undertones of Frederic with the priest quoting "Rinaldi's suspicion that the priest and Henry are a little "that way" (14) and the lesbian undertones of Catherine and of Ferguson as Miriam Mendel says that "Helen inhabits every Italian setting in which [Catherine] appears"; indeed, "she seems to be [Catherine's] constant friend" (18). Frederic's sexual relationship with the whores as described by Moddelmog is Frederic's alienation from understanding true love as the priest predicts "what you tell me in the nights. That is not love. That is only passion and lust. When you love you wish to do things for. You wish to sacrifice for. You wish to serve" (66). Moddelmog supports the priest's speech that "thus, the lesson of true love is sharpened by its contrast to the lustful, selfish, and ultimately empty one-nights stands with prostitutes" (10). Moddelmog infers that sex with prostitutes while drunk makes Frederic away from the disturbances of the war; but, particularly, sex with prostitutes alienates him wholly from seeking peace and pure love that he feels later with Catherine.

Moddelmog, from A Farewell to Arms, quotes a line,that she believes to have stressed the queer sensibility of Frederic, who is not married to Catherine, reports that "we said to each other that we were married the first 
day she had come to the hospital and we counted months from our wedding day" (11). These characters are seen to be quite unaware of what or who they are; specially in Frederic Henry's case, he is seen as being mostly disillusioned about who he is.

\subsection{Purpose}

Therefore, from the background of Frederic's identity predicament, alienation is critically drwan as being the defining key argument of the essay. The term, alienation is much broader a concept but in this essay, the concept of alienation argues about Frederick Henry's alienating identity as opposed to his inability to be socially identified. In accordance with Compact Oxford English Dictionary, alienation is defined as "making someone feel isolated or estranged". In addition to this, alienation can be, in general, a person's condition of being culturally and emotionally excluded from family's root, institution or feeling. Patrick Colm Hogan rightly points out that "clearly alienation is not in itself an experience one chooses to have; it is, rather, an inability to enact any choice -an inability, as we shall see, frequently associated with emotional and mental disintegration" (88). In a similar way, Hogan also suggests to alienation as a kind of "cultural disintegration involving a sense of alienation from all cultures, being 'no longer at ease' in any cultures, finding a home neither in indigenous tradition nor in Europeanization" (88). Frederic's alienation is that he displays a kind of detachment towards the truth that he is an American; he detaches himself from his seeming optimism of First World War he gets involved in. Later when his traditionally romantic vision of life connected with profound feeling and strong emotional tie with his beloved is triggered by his beloved's dying of hemorrhage; it then constitutes the fabric for the complexity of Frederic Henry's identity. In fact, Frederic Henry's experiences of alienation in Hemingway's A Farewell to Arms could be argued to have portrayed a world of isolation in which humans felt distanced from their roots because although the genre of $A$ Farewell to Arms does start with an elucidation of a love plot, the portrayal of deliberate infliction of suffering of an illogical war ultimately formulates alienation as the tragic end. Throughout the plot of the novel, alienation expresses itself through many characters, specially through the protagonist, Frederic Henry, whose mental and emotional states get severely sickened having been disintegrated by his unremitting failure to have an identity; and his unremitting doubt about his identity dilemma. Frederic discloses this to his beloved that "you see I've been leading a sort of a funny life" (25).

\subsection{The Aim/Contribution of the Paper}

As the research will see, Frederic suffers greatly from alienation being failed over and over again to identify himself. As the novel delineates his alienation, this research will argue that Frederic's alienation occurs in three particular areas. Firstly, he is alienated from his American ethnic identity. Secondly, he alienates himself from First World War; and, is, eventually, alienated from his love to Catherine with whom he was hoping to have a peaceful life. The framework of Frederic Henry's alienating persona is visible from various angles of reflection, that is, no clue is provided in the narrative that Frederic thinks going back to his native country while Niclas Martinsson points out that Frederic's American roots, although he is not mocked by the Italians, make him feel alienation. Furthermore, Frederic's holding of the position of an ambulance driver contrasts to the position of a regular soldier; and this also increases his sense of not belonging in Italy. Frederic says that to Rinaldi that "what an odd thing - to be in the Italian army. It's not really the army. It's only the ambulance" (17). Rinaldi agrees with Frederic and asks him as to why he has to do the job while, in return, Frederic replies that I don't know (17). At the end, the death of Catherine Barkley leaves him in a precarious as well as more highly susceptible position which insinuates that, like Earl Rovit puts forth, Frederic becomes somewhat "humanly alive" by the end (105) indicating a sign of a man of alienating persona of which Martinsson argues that "the death of Catherine makes Frederick reject all kind of belief in anything, return to the detached position he started out from" (17).

\section{Frederic Henry's Alienationfrom His American Identity}

The narrative of Frederic brings a problematic world into focus; within that area of world, Hemingway produces alienation triggered by First World War in a broader sense because it has been the major historical problem of his time. Unfortunately, Frederic's rootlessly being in Italy at the beginning bears a token of alienation from his home. The novel opens with Lieutenant Frederic Henry, who frequently visits cities like Milan, Florence, Rome, Naples, Vila San Giovanni, Messina, Taormina to seek adventures with beautiful Italian girls but does not visit Abruzzi the priest's home. Frederic admits:

I had gone to no such place but to the smoke of cafes and nights when the room whirled and you needed to look at the wall to make it stop, nights in bed, drunk, when you knew that that was all there was, and the strange excitement of waking and not knowing who it was with you, and the world all unreal in the dark and so exciting that you must resume again unknowing and not caring in the night, sure that this was all and all and all and not caring. (13) 
Robert Penn Warren describes that "Frederic at the opening of the novel lives in the world of random and meaningless appetite, knowing that it is all and all and all, or thinking that he knows that. But behind that there is a dissatisfaction and disgust" (29). Frederic's escape from the priest's 'clear', 'cold', 'dry' country (12) displays a vague meaningfulness of some kind of life Frederic lives up to it's fullest; in that world, the view of life the priest is not acquinted with because the priest loves God.

The protagonist narrates how he feels about a home that clearly means family, attachment or bond but in $A$ Farewell to Arms, while 'home' is found as being an illusory object, that Frederic never finds anywhere, 'not home' indicates nervousness and suffering that are available for him. Literally, 'the Home' and 'the Not-Home' are not accurately conceptualistic as Carlos Baker demonstrates that each of the concepts is poetically taken knitted into emotional ties:

The 'Home-concept', Baker says, is associated with the mountains; with dry-cold weather; with peace and quiet; with love, dignity, health, happiness, and the good life; and with worship or atleast the consciousness of God. The Not-Home concept is associated with low-lying plains; with rain and fog; with obscenity, indignity, disease, suffering, nervousness, war and death; and with irreligion. (102)

With realization of Frederic's situation in 'not home' condition in the narrative structure of $A$ Farewell to Arms, Michael John Macdonald IV could be argued to specify Frederic's state of alienation. Macdonald IV argues that "Frederic's fortunes alternately rise and fall with the narrative structure, emphasizing the idea that home is an illusion, whereas not-home is the reality of pain and suffering" (47). There it is Frederic, who lives in a sense of emptiness, and of disillusion due to his inevitable defeat to the dehumanized world in which his personal quests for an identity are doomed to failure because he is to lose everything. Peter Messent argues that "[Hemingway's] fictional subjects are peculiarly and strongly alienated from the everyday world $[\ldots]$ and seem to exist in a type of ideological vacuum because of their inability to find any meaningful and positive connection with the larger public arena" (6). Macdonald IV is recognizedby some critics presenting Hemingway's inherent dualities as home and not home in A Farewell to Arms.

Macdonald IV argues "as the plot of $A$ Farewell to Arms unfolds, Hemingway produces a dichotomy where a sense of normalcy and structure is an illusion and the reality is absurd and chaotic" (46). Macdonald IV suggests that "the question of what is 'real' and what is 'illusion' permeates the novel (46). At this point, as the narrative opens with Frederic Henry serving for the Italian army, a question that arises in this research is why he has to be an American volunteer in Italy at the first place. Observing the text's protagonist having been a man without a country, a series of iconographies of alienation, or estrangement come to the readers' minds; in that, the images of the protagonist's alienation can possibly call those readers for making a scrutinizing visit to the background of the world in which this text was written. However, before mentioning how Frederic is alienated from America, this research argues that the American dream's failure that has been caused by the great depression originated from First World War as being the pure reason for Frederic's growing distrust in America; and leaving from there. The American dream in 1907 was an immidiate event just before the devastating First world War in 1911.

The American dream was an idea that one will make one's fortune through self help. Jim Cullen suggests that "it's as if no one feels compelled to fix the meanings and uses of a term everyone presumably understands-which today appears to mean that in the United States anything is possible if you want it badly enough" (5). At that time, the aspiring politicians, businessmen, common people, and immigrants cherish this newly formed belief in their heart. In a word, it has become for them an ultimate goal, which they pursue in the way as if it was their destiny. Cullen points out "the politicians invoke it as the basis of their candidacies and the businessmen cite achieving it as the ultimate goal of their enterprise" (5). A lot of immigrants came to the American land of the dream, and eventually, many of them succeeded. As a result, it became very popular among the people. In short, as Cullen suggests "they will be one who overcomes the odds and gets rich, is the one of a great themes of American policies" (7).

Everybody was used to dream of their success but, in reality, the dream had no specific concrete structural basis. It was just a dream, which was taken as a policy out of an independent thinking and selfdevelopment for the American nation after America was liberated from the Kingdom of Great Britain on $4^{\text {th }}$ of July, 1776. It seemed to have become for the American as the 'national American identity' according to Cullen. But because of its having no concrete structure, and at the rise of industrialization, it was losing its hold over the people. Cullen says, "Large transnational institutions like corporations shape the lives of ordinary citizens for more than local government"; added that, he says, "Economic and racial stratification have grown markedly, raising doubts about the breadth and depth of the opportunity" (6). A lot of people came to America to search for a better life but their hope could not bring economic security for them. Then the dream is marked by a sense of uncertainty, and gradually, people become skeptical toward it. The allegiance it made with others started disintegrating. Finally the American dream broke down with all its cherished hope, and people became disillusioned about it when America entered First World War. "The Italians were sure America would declare war on Austria too and they were very excited about any Americans coming down, even the Red Cross" (70). 
The character of Frederic in A Farewell to Arms is assumed to shape his identity by this American national policy. But his disillusionment may occur when he sees that the American dream was broken. He perceives himself as an alienated man as a conflicting nature of Frederic's identity can be observed in the very beginning when a nurse asks that "you are the American in the Italian army? Why did you join up with the Italians?". Frederic replies that "I was in Italy, and I spoke Italian" (21). Stephen Greenblatt argues that "the conflict could be investigated, on performance by-performance basis, in a history of reception, but the history is shaped by circumstances of production as well as consumption" (787).

To justify Greenblatt's investigation, the strategies of the American dream that shapes alienation for Frederic signify the conflicting background of America's cultural disintegration at that time. Andrew J. Wilson points out, "Ferguson's remarks concerning Frederic's ambiguous national identity, or unidentity, point to the hero's poignant failure to be an authentic inhabitant of any particular place" (56). According to this view, Frederic's life can be investigated in his search of an identity of himself, that is, what his real identity is. As Lisa Tyler adds, "his past is a blank, for Hemingway tells us next to nothing about Frederic's childhood (63). Therefore, in the beginning he is presented as being a rootless man. Earl Rovit and Gerry Brenner point out that "even in his native land he is rootless. He has a stepfather somewhere in America, but he has quarreled so much with his family that the only communication between them is in their honoring of his sight drafts (83). Frederic seems to have experienced a kind of insecure future and lived an unmanly life in America. As a result, this research paper argues that he decides to leave America as if he felt a sense of disagreement with the validity of the American dream as well as it's future prospects. Wilson states that "Frederic may have found America to be incapable of providing him with things he needs and wants (56). Instead he seeks for a stable life in Italy. He goes there during First World War. Rovit and Brenner find Frederic out in Italy as "an unrooted American disguised in an Italian uniform" (83).

\section{Frederic Henry's Senseof Alienationfrom First World War}

Frederic joins the war in Italy after being disillusioned by the fall of the American dream. Hence, the character of Frederic in the Italian front is made more identifiable with a rank of a second lieutenant to the ambulance job, but he does not do the job for any patriotic reason; rather the war excites him intensely that he feels released from the inertial and unmanly life once he led in America. The war exposes a kind of chivalric or heroic impression upon him; as a result, he makes a personal code of conduct that is exemplified in his macho style of living, such as, showing off masculinity, drinking alcohol and womanizing. As Wilson explains, "but when A Farewell to Arms opens, Frederic is a man who tends to see the world through a military lens. He enjoys the male camaraderie of war, especially his relationship with Rinaldi" (60). As Frederic thinks that the war is a masculine zone, his military uniform signifies his sense of masculinity and Catherine's initial refusal to love hurts his masculine ego. He talks to himself that "I was experiencing the masculine difficulty of making love very long standing up" (29).

So, it is clear that the military uniform is a symbol of power to Frederic, and when he wears this, he feels no fear. He tells Rinaldi that "well, I knew I would not be killed. Not in this war. It did not have anything to do with me. It seemed no more dangerous to me myself than war in the movies" (35). In truth, Frederic's self-fashioning as a masculine man in the war probably stresses his historical background of inaction. Particularly, before First World War, men have obsessive interest in knighthood and chivalric life and men especially the young men are quite moved by this medieval tradition of knighthood and chivalric war. John $\mathrm{H}$ Morrow in The GreatWar asserts that "the arrival of war in august 1914 would release young men from the constraints of a dull, materialistic society to find their escape and fulfillment in the grandest enterprise of all" (19).

Therefore, to speak with Morrow, the war also releases Frederic from the boredom and gives him the grandest enterprise. Rinaldi tells Frederic that "you are really an Italian. All fire and smoke and nothing inside. You only pretend to be American. We are brothers and we love each other" (56). In fact, Frederic's refashioned identity is exemplified in Rinaldi words. Frederic is severely injured by a trench one day when he is eating macaroni and cheese; and all of his chivalric notions of manliness about the war disappear. Frederic describes that "I ate the end of my piece of cheese and took a shallow of wine. Through the other noise I heard a cough, then came the chuh-chuh-chuh-chuh- then there was a flash, as when a blast-furnace door is swung open, and a roar that started white and went red and on and on in a rushing wind" (51). Then he feels a mortal pain both physically and mentally. He conceives that the war as inglorious and infernal. Tyler discloses that "in writing the passage describing Frederic's wound (one of the most memorable passages in the book), Hemingway drew on his own experience of being wounded in the leg by shrapnel July 8, 1918, while he was distributing chocolate to troops at the front" (61). Frederic reasons that the war draws on its imperial goal; there is no better cause to which it aims at. Wilson states:

Finally during the retreat in Book Three Frederic hears that German soldiers 
wearing Italian uniforms are breaking through the lines. This instance of infiltration or breakdown of identity perfectly symbolizes the confusion in

Frederic's mind, which reaches its zenith during the retreat. Eventually

the war is nonsensical for Fredric, and he cannot remember

why he ever became a part of it. (61)

Frederic feels as if the trench mortar shell alienates his body from his breath. He says, "I tried to breath but my breath would not come and I felt myself rush bodily out of myself and out and out and out and all the time bodily in the wind (46).

However, he is taken to the hospital, where he is informed about a reward of 'a silver medal of valour' by Rinaldi as if Rinaldi thinks that Frederic won a battle or did a spectacular heroic performance in the war. Frederic's receiving of a silver medal as a reward brings home a greater irony at the climax because while he needs an intensive clinical service, Rinaldi comes up with a business of declaring rewards to Frederic, who is suffering from the screams of shells. Rinaldi starts:

Tell me exactly what happened. Did you do any heroic act?

No,I said. I was blown up while we were eating cheese.

Be serious. You must have done something heroic either before or after. Remember carefully. I did not. Didn't you carry anybody on your back? Gordini says you carried several people on your back but the medical major at the first post declares it is impossible. He had to sign the proposition for the citation. I didn't carry anybody. I couldn't move. That doesn't matter, said Rinaldi. (59)

Frederic realizes that there is no sign of hope and meaning he is pursuing for in the voraciousness of the war as the more ruthless and toughened the war takes on. In short, A Farewell to Arms depicts Hemingway's vision of the world as full of brutality and disillusionment about life and home. Frederic explains the nature of the war by telling that "there is a class that controls a country that is stupid and does not realize anything and never can. That is why we have this war. Also they make money out of it" (48). Even if any regiment accidentally fails to operate it's advance, it is accepted as an act of cowardice; consequently, every 'tenth man' is then shot not as a punishment but as a warning to others:

Were you there, Tenente [asks one of the ambulance drivers], when they wouldn't attack and they shot every tenth man?" "No."

"It is true. They lined them up afterward and took every tenth man. Carabinieri shot them. (46)

Thus Frederic has to run away from the war as he has neither further enthusiasm to adhere to the war nor meets any chances he can use to identify himself. His disillusionment about the war occurs when he is caught by the Italians, who think that he is a deserter and, consequently, they order to shoot him. Saving himself, he jumps into the river in Tagliamento. He says that "I ducked down, pushed between two men, and ran for the river, my head down" (176). His jump into the river explicitly refers to his second alienation from First World War with his all obligations. He speaks to himself after he comes to the shore:

Anger was washed away in the river along with any obligation. Although

that ceased when the carabiniere put his hands on my collar. I would like to

have had the uniform off although I did not care much about the outward forms. I had taken off the stars, but that was for convenience.

It was no point of honor. (206)

The character of Frederic takes the chance of the war, as he says to Rinaldi that "America is in the war" (70) but when Frederic observes that the soldiers crying out of their bloody injuries, he fails to see glory dying inside the battle. Frederic's obligations to the war could be understood by his preference of concrete descriptions and dialogue in contrast to the abstract words like glory or sacrifice. He encounters cruelty of war, death, and wounded soldiers as he narrates that "in the jolt of my head I heard somebody crying. I thought somebody was screaming. I heard the machine-guns and rifles firing across the river and all along the river" (51). He sees that "it was Passini and when I touched him he screamed. His legs were toward me" (51). Frederic sees that "they were both smashed above the knee. One leg was gone and the other was held by tendons and part of the trouser" (52). Hence, Frederic observes that the priest's words such as glory, love, mercy, sacred have to surrender to the concrete particulars what the violence of the war has to offer to the general soldiers. Even, afterwards, Frederic's own alienation from the war shall as well be triggered by the same violence of the war. The society in which he has to accommodate in does apparently make him sinking into disillusionment as Robert Merrill states that "Frederic is disillusioned with society no less than with his family or religion. The "order" of society has been unmasked by the war society has conspired to make" (577).

Merrill further points out that "the 'mistaken' actions of the hero have nothing to do with his fate, unless we would perversely judge Frederic for choosing to love Catherine. The assumption underlying this tragedy is that the enemy is not only within-it is also out there, in the universe itself' (578). Even Frederic admits that he, indeed, was not against the war but he does not want it because he realizes that it is not his: 
I was not against them. I was through. I wished them all the luck. There were the good ones, and the brave ones, and the calm ones and the sensible ones, and they deserved it. But it was not my show anymore and I wished this bloody train would get to Mestre and I would eat and stop thinking. I would have to stop. (206)

It is evinced in the narrative that the war was described by Hemingway as being a power that fashions Frederic's life with a tragedy; as a result, the tension could revolve around the audience's expectation for Frederic and fate of Frederic. In comparison with the power of war, Frederic is made to show passivity in his actions. So, this research argues that he is a 'moved' character rather than being a 'moving' one. His passiveness and wound received by the trenches could be intelligible in his own utterances:

I went out swiftly, all of myself, and I knew I was dead and that it had all been a mistake to think you just died. Then I floated, and instead of going on I felt myself slide back. I breathed and I was back. The ground was torn up and in front of my head there was splintered beam of beam of wood. (51)

After he realizes, he observes that his romantic sensations towards the war contrast to it's practical impact on his life, and consequently, he has to be disillusioned about the war's purpose. Frederic escapes the war because he has to. He has neither patriotism for Italy nor has hatred for Austria. He is not really a soldier but is an ambulance. When Catherine asks him for the reason of his joining Italy, he replies that "I don't know. There isn't always an explanation for everything" (17), though he also finds it unreasonable to live and die meaninglessly even in Italy at the end. Masaya Takeuchi is of the argument that "but a trench motor, which kills Passini and wounds Frederic's leg, forces him to realize the brutality of the war and the powerlessness of soldiers in face of the technological power of the war" (31).

\section{Frederic Henry's Final Alienationfrom Catherine Barkley}

As Frederic flounders in Italy, he lets all of his difficulties be with the war; and elopes with Catherine Barkley to Switzerland. He exchanges his 'war's arms' for the 'arms of Catherine Barkley'. Wilson argues that "indeed it seems that Catherine, and Frederic's love for her, anchors him to reason in 'the landscape of unreason" (62). Frederic's refashioned identity as 'code hero' in the war is gone because of his excessive indulgence to Catherine; but he does not think about that; and refashions again as a passionate lover. He understands that it is only Catherine in whom he gets some peace. Frederic says, "'Yes', I said. 'And we have gotten away from the war.' She laughed. It was the first time I had ever heard her laugh" (25). Macdonald IV suggests that "Catherine and Frederic are drawn to each other through an illusion of love, seduction, and comfort that offers Catherine solace after the death of her fiancé and Fredric, a distraction from the war" (46). Catherine's love makes Frederic dream of a new hope in his life again; and he is found to be no stereotypical male anymore he was used to be in the battle. When he is admitted in the hospital he inquires if Catherine is coming. He says that "I heard someone coming down the hallway. I looked toward the door. It was Catherine Barkley" (84). He then asserts to her, "I'm crazy about you. I'm mad about you. Come on, please. Come on, please, please, please" (74). This clearly states his surrender to her. He is seen to be dependent on her slowly. Messsent says:

The inversion of sexual roles in Hemingway's fiction, the uncertainty

of his male protagonists' sense of their own manhood, and the divided and contradictory nature of his discourse of sexuality and gender are all mar-kers of a deep concern about masculine identity which are under acute threat. (87)

Frederic's putting off the military uniform and putting on the civil dress indicate his exchange of war for love. Frederic admits by himself, "Knotting my tie and looking in the glass I looked strange to myself in the civilian clothes. I must remember to buy some more shirts and socks" (229). He searches for Catherine, and knowing that she is in Stresa, he boards on the train to Stresa thinking that "I was going to forget the war. I had made a separate peace." (217). It is seen as Wilson points out that "sickened by a crisis of masculinity brought on by the strictly male-dominated, callous sphere of war, he is gradually redeemed, however subtly, by the tenderness of an imperfect but loving woman's presence and passion" (65). For Frederic, Switzerland is a symbolic paradise, where he declares oneness with Catherine, who redeems him from the callousness of the war. She is presented as a more heroic person, a ready woman for Frederic, and governs an alienated man like him. She reflects herself as a new woman of 1920s. A new woman is a tomboyish woman, who smokes, drinks, gambles, drives car, plays golf, and keeps hair short. Frederic himself discloses that "Miss Barkley was quite tall. Was blonde and had a tawny skin and gray eyes. She was carrying a thin ratten stick like a toy riding-crop, bound in leather" (18). He says to her, 'You are brave', which means that Frederic is no more courageous; he seems to lose his phallic authority over her. Catherine retorts that 'No. But I hope to be', which indicates the spirit of a 'new woman' in Catherine.

When Frederic insists Catherine of not cutting her hair, she replies him that "I'm tired of it (266) and suggests that "it might be nice short. Then we'd both be alike" (266). When she insists Frederic on growing his 'beard', he agrees and that signifies re-definition of his masculine identity. Takeuchi points out that "his wounding renders him passive" (31). Catherine is represented free and strong at the end, when she assumes the 
subjective position while Frederic, the objective position. In the words of Takeuchi, "throughout the novel, Catherine transforms from the object of male desire into the controlling subject of male desire" (38). While having his first sexual moment with Catherine in the Milan hospital, Frederic has to allow her on top of him. Consequently, he then becomes sexually receptive and, at the same time, feminized. Mark Spilka points out that "he would have to lie on his back to perform properly, given the nature of his leg wounds, and Catherine would have to lie on top of him" (212-13). Catherine teases Frederic saying that "Othello with his occupation gone" (198) as Frederic is merged in her completely. By referring Othello to compare with Frederic, as Wilson puts, Hemingway reminds the audience of:

A man who perhaps cannot accept ambiguity, who tries to impose upon

all things a reductionist, military notion of right or wrong, whether or not he

is dealing with military concerns. The result of such one-sided vision, the

authorial voice behind A Farewell to Arms knows, is ruinous. So Hemingway also seems to be showing his readers how his hero is more willing than Shakespeare's to accept that there is no single way to deal with 'the complicated business of living. (63)

In short, Frederic fashions and refashions his identities by playing various acts because assuming any identity; or, constructing a gender cannot be somatic as it is rather performative. Judith Butler, in this case, offers that "gender is in no way a stable identity or locus of agency from which various acts proceede; rather, it is an identity tenuously constituted in time-an identity instituted through a stylized repetition of acts" (519). In this connection, Frederic's show of stoic masculinity in the battle is not determined by his muscle but by his performance as a lieutenant. In the same way, his identity is again determined by the performance of his remarkable resemblance to Catherine. Thus, his identity is resolved internally, that is, phantasmatic, which is not connected with gender. Catherine is also supposed to be behaving almost like Frederic in the end than her looking to be inferior at her initial approach to him. To speak with Butler again that "the gendered body is performative suggests that it has no ontological status apart from the various acts which constitutes its reality"(173). Thus, various acts of Frederic create his various identities. His identities are changed with his different power relations also; in that his character can be seen sometimes as original [male genitalia], and also as the parody [female nothing] in terms of Butler's 'performative'. Frederic's identity is also confused by his own utterances. He says that "I'm very brave when I've had a drink" (111). According to Crary Alice, Frederic's being 'brave' can be considered as a performative utterance because it is likely to be a promise that he will be a brave after a 'drink' but it is not clear if he will be. So, Frederic's utterence of being 'brave' is neither true nor false. Moreover, when Catherine says that "I know brandy is for heroes", she indicates for heroes but probably she does not mean for Frederic because all of his heroic gender pride is already gone. It does not describe a state of affair because he cracks in the end; and he says to her that "I'm not brave any more, darling. I'm all broken. They've broken me. I know it now" (248).

Frederic fails to retain his stoic masculinity any longer of which Butler says that Frederic's gender is parodied because his commanding personality shown in the beginning turns to a submissive one at the end. His retreat from the war can be demonstrated as a reaction to the modern complexities of life. His leaving the complexities of the war; and embracing love of Catherine reminds readers of the modern fantastic love affair of a man, who flees with Catherine into the pastoral romantic land of Switzerland. Their love can be compared with the love affair of Romeo and Juliet but the cultural tension of Frederic's time fashions the ending unlike Romeo and Juliet. Frederic's search for a personal wholeness with Catherine is marked by impending uncertainty and alienation. Sheridan Baker calls Frederic's planned search "of happiness of the Garden that a man must lose" (460).

In Switzerland, Frederic lives three months of happiness with Catherine that marks a complete reunion of two disturbed souls. Scott Donaldson argues that in Hemingway's literary imagination, these attempts to recover paradise take two basic forms. "The first occurs away from civilization, in the outdoors, where men might discover a transcendental oneness with the universe and the second occurs through a complementary reunion with a member of the opposite sex" (175). Frederic could find out his ideal woman to live with, but could not find out the ideal place to live in. Hemingway's literary imagination draws on the bleak end in this novel because he wants to show that Frederic's relentless search for civilization, or better life from the beginning till he lives in Switzerland will rest on futility. Frederic escapes from the uncivilized world of the war but he is not confirmed about if the civilization does really exist he is searching for at the advent of First World War. This is clarified when Catherine dies at the end in the operation theatre. He loses his last belonging in the world. He thinks that war is going on in the Italian front but not in Switzerland; despite that she dies in Switzerland. Catherine cries out by admitting that "it's just a dirty trick" (292). Frederic's experiences go climax as he states that "it seems she had one hemorrhage after another. They couldn't stop it. I went into the room and stayed with Catherine until she died. She was unconscious all the time, and it did not take her very long to die" (293). In his every attempt to recreate a meaning of life, there is always an underlying alienation. Donaldson says that " $A$ Farewell to Arms, where Edenic life becomes for a time the center of the story, paradise in Hemingway's fiction 
can, at best, only be glimpsed" (175). Frederic's loss of Catherine assures him of the most powerful alienation that gives a final shape to his identity.

He becomes what he has been, and which he has been trying to run away from. While Frederic's private life with Catherine signifies his search for a home of tranquility, his public life universalizes alienation because his private life observes only death and broken dreams. In this case, his public life seems to be mocking at his private happiness with Catherine, and his desire for home, and making family with her because Macdonald IV suggests that "In A Farewell to Arms, Hemingway shows that happiness is an illusion based solely on perspective, and that illusion offers only a temporary shelter from the real" (47). Therefore, Frederic's experience of his public life is tremendously connected with his horrifying private life. As A Farewell to Arms unfolds, M. Keith Booker sees a relationship between the storyline, and the contemporary society. By looking into the contemporary society as well as the author's own private life and public life colored with the reality of alienation, Frederic's private life, and public life can be clearly realized. Booker states that "The new historical methods inspired by the work of thinkers such as Foucault and Geertz produce not only a distinctive style of literary criticism but also a distinctive vision of the relationship between literature and society" (138). So, the novel's story is partly fictional for its characterization, and descriptive method; and partly based on its author's practical experiences, such as, his job as an ambulance driver in First World War, his leg wound in the war, his abortive romance with Agnes von Kurowsky in the war; and also his career in journalism.

Frederic is seen to adopt almost all of Hemingway's practical experiences in the novel. Gerry Brenner, in this regard, identifies that "throughout his career recurring stints of journalism and ventures into nonfiction nudged aside Hemingway's writing of fiction" (446). In this case, the theme of Frederic's alienation in $A$ Farewell to Arms has a connection with Hemingway's own feeling of alienation from his family he lived earlier; his four marriages; his affair with Agnes von Kurowsky in First World War; his having taken part in First World War; and his getting involved into journalism. J.F. Kobler explains that "Hemingway's journalism reports an experience while his fiction conveys the emotions created by the experience" (446). Though Hemingway narrates Frederic's disillusionment about life as well as Frederic's alienation, but implicitly Hemingway delivers a message of alienation trauma of his contemporary time. In this way, Hemingway was argued by Kobler that Hemingway lets his made-up characters be more remembered through his novels. Like those of Hemingway's characters, Frederic in, A Farewell to Arms, could also be immortalized, and while reading alienation of Frederic, the real traumatic encounter of alienation will also be repeatedly articulated. Therefore, in accordance with Kobler's statement, in A Farewell to Arms, Frederic's alienation is made evident by Hemingway's legitimate sentiment of the pointlessness of searching life. This sentiment of ineffectuality of life is exposed through Frederic, who admits that "the world breaks everyone and afterward many are strong at broken places. But those that will not break it kills. It kills the very good and the very gentle and the very brave impartially" (222). Diane Price Herndl also looks into this aspect and states that "such sentiments are perhaps typical of a postwar modernist disillusionment, an alienation focused on pointlessness of life and manifested later in existentialism" (42).

It is alienation, which Frederic must meet. Randall S. Wilhelm argues that "the objects placed throughout the narrative, however, with their semiotic massages of guilt and anxiety regarding Henry's role in Catherine's death, tell quite a different story" (77). Kenneth Lynn puts that Frederic's response to Catherine's death looks "a nonreaction" and Lynn is of the opinion that Frederic "does not appear to be in shock" (390). On the other hand, Wilson argues that "but Lynn fails to account for ambiguity in the way people respond to death, even when the dead are beloved" (64). Actually when Catherine dies, Frederic's immediate response to her death could not be fixed, but it could be realized that he thinks her death utterly senseless. He turns dismayed and all broken. He says that "it was like saying good-by to a statue" (293). Tyler says that "when Catherine hemorrhages and dies a few hours later, a stunned Frederic is left with nothing" (62). According to Lynn's contention, Frederic becomes again "the hollow man" as he had been before. Alienation is Frederic's identity the author might think about him that Frederic has to embrace at last. Up to the point of Frederic's eminent loss of his last happiness, he discloses his deep feeling to himself for Catherine:

I went out the door and suddenly I felt lonely and empty.

I had treated seeing Catherine very lightly, I had gotten somewhat

drunk and had nearly forgotten to come but when I could not see

her there I was feeling lonely and hollow. (39)

\section{Conclusion}

A Farewell to Arms ends with Frederic's final separation from Catherine. Hemingway's style of such ending reflects particularly his own worldview. Catherine's death finally shapes Frederic's real identity; the identity of alienation that is destined by the author; and the identity that is permanent. Frederic becomes lonelier a person at the end, and finally, he realizes 'as being lonely' is the remaining identity for him in the degenerative world of alienation. Takeuchi explains that "Frederic must have mourned the loss of Catherine and refrained 
from loving women who cannot share his nihilism" (42). A man's becoming strong or seeking for home is shown as a pose in A Farewell to Arms. This essay discusses some eventful episodes such as the failure of the American dream, the violence brought by First World War, and the destruction of home that lead Frederic to insecurity, and alienation. Frederic, as a spokesman, comments on these historical events depicted in the narrative throughout his whole journey of life. Frederic escapes America for his failure to accommodate there; and joins First World War arriving in Italy. When he also fails to find a identity in the war, he tries to find in Catherine Barkley's love fleeing with her to Switzerland. But when Catherine dies, it sounds like a final note of fatalism for Frederic. It is seen as if his search for his identity was ridiculed by his fate.

Throughout the narrative he is seen to be making home with Catherine in the hospital, or in a hotel in Milan, or on a boat but he cannot make a home forever with her in any country. Though he endeavors to make a family in Switzerland with Catherine, but he breaks ultimately. He expresses that "if people bring so much courage to this world the world has to kill them, so of course it kills them" (56). His endless mental agony can, at least, be glimpsed in his last sentence "After a while I went out and left the hospital and walked back to the hotel in the rain" (256). Notably, the rain reminds the reader of how Catherine feels about it. She once said to him that "I'm afraid of the rain because sometimes I see me dead in it (100). Significantly, Frederic shares the same feeling of death in the rain as he walks out into it. As many other fictions, A Farewell to Arms also presents a narrative of a male protagonist but the background it deals with signifies many real men whose lives probably meet the same consequence affected by First World War. Hemingway presents an argument regarding redifining gender in A Farewell to Arms after America enters into First World War.

The American dream's optimism is questioned by the war that brings home economic crisis and alienation. Frederic fights with his culturally alienated identity to know who he is, as Martinsson subtly points out that "To what extent Frederick's identity depends on the feelings of rootlessness and the perceived alienation can only be left to speculation, but the assumption - whatever be the reason - that he does not quite know who he is, must not be denied" (2). The war brings in Frederic cynicism instead of hope. So, when the narrative's end results in Frederic's bidding farewell to Catherine also, it appears as Martinsson explains "that Frederick has a somewhat negative and cynical world view; at heart he believes that there is really no use in believing in anything because, in the end, the cruelty and the mercilessness of the world will take those beliefs, laugh at them and throw them straight in your face" (3). Hemingway, in the narrative, gives an clear sign of alienation of Frederic through the character of George, who tells Frederic, "That's all right, Tenate'. I know how it is. I know how a man gets short" (89). Indeed, up to the point of George's comment on Frederic's failure to enact an identity, George indicates that Frederic gets alienated in modern time. Wilhelm suggests that the forlorn lover 'tricked' into love by a cruel world that seeks to destroy him" (77).

\section{Books:}

[1] de Beauvoir, Simone. The Second Sex. Trans. H. M. Parshley. New York: Vintage, 1952. Print.

Journal Papers:

[2] Barlowe-Kayes, Jamie. "Re-Reading Women: The example of Catherine Barkley" The Hemingway Review 12 (1993): 24-35. Print. Journal Papers:

[3] Hewson, Marc. "The Real Story of Earnest Hemingway: Cixous, Gender, and A Farewell to Arms" The Hemingway society 22(2003): 51-63. Print.

Journal Papers:

[4] Robert E, Gajdusek. “A Farewell to Arms: A psychodynamics of Integrity”. Hemingway society 9 (1989): 26-33. Print.

Journal Papers:

[5] Moddelmog, Debra A. "We Live in a Country Where Nothing Makes Any Difference: A queer Sensibility of $A$ Farewell to Arms" The Hemingway Review 28 (2009): 7-28. Print.

Journal Papers:

[6] Mandel, Miriam. "Ferguson and lesbian Love: Unspoken Subplots in A Farewell to Arms" The Hemingway Review 14.1 (1994): 18-24. Print.

Dictionary:

[7] Catherine, Soanes, and Hawker Sara, eds. "Alienation." Def. 2. Compact Oxford English Dictionary of Current English. 3rd, Revised ed. 2008. Print.

Journal Papers:

[8] Hogan, Colm Patrick. "The Gender of Tradition: Ideologies of Character in Post- Colonization Anglophone Literature" Order and Partialities. Ed. Myrsiades and Mcguire. New York: NSP, 1995. 87-110. Print.

Theses:

[9] Martinsson, Niclas. A Subtle Slide towards Commitment: Frederick Henry's Identity in A Farewell to Arms by Ernest Hemingway. Diss. Lund University, 2008. Print.

Books:

[10] Rovit, Earl, and Gerry Brenner. Ernest Hemingway. Boston: Twayne, 1986. Print.

Books:

[11] Hemingway, Ernest. A Farewell to Arms. England: Harmondsworth, 1970. Print.

Books:

[12] Hemingway, Ernest. A Farewell to Arms. London: The Random House, 1957. Print.

Books: 
[13] Hemingway, Ernest. A Farewell to Arms. London: Arrow Books, 1957. Print.

\section{Journal Papers:}

[14] Penn Warren, Robert. "The Story Behind the Love Story" Ernest Hemingway's A Farewell to Arms. Ed. Harold Bloom. New York: Infobase Publishing, 2009. 27-34. Print.

Books:

[15] Baker, Carlos. Hemingway: The Writer As Artist. Princeton:

Princeton University Press, 1972. Print.

Journal Papers:

[16] Macdonald IV, Michael John. "Hemingway's A Farewell to Arms" The Explicator 67 (2008): 45-47. Print.

Books:

[17] Jim P, Cullen. A Short History of an Idea That Shaped a Nation. Cary: OUP, 2003. Print.

Journal Papers:

[18] Greenblatt, Stephen. "Invisible Bullets" Literary Theory: An Anthology. Ed. Julie Rivkin and Michael Ryan. Malden: Blackwell, 1998. 786-803. Print.

Journal Papers:

[19] Wilson, Andrew J. "Bidding Goodbye to the Plumed Troop and the Big Wars: The Presence of Othello in A Farewell to Arms" The Hemingway Review 15(1996): 52-66. Print.

Books:

[20] Tyler, Lisa. Student companion to Ernest Hemingway. Westport: Greenwood Press, 2001. Print.

Books:

[21] Morrow, John H. The Great War. New York: Routledge, 2004. Print.

Journal Papers:

[22] Merrill, Robert. "Tragic Form in A Farewell to Arms" American Literature 45 (1974): 571-579. Print.

Journal Papers:

[23] Takeuchi, Masaya. "Frederic's Conflict between Homosociality and Heterosexuality: War, Marvell, and Sculpture in A Farewell to Arms". The Midwest Quartely 53 (2011): 26-44. Print.

Books:

[24] Messent, Peter. Earnest Hemingway. London: The Macmillan Press, 1992. Print.

Books:

[25] Spilka, Mark. Hemingway’s Quarrel with Androgyny. Lincoln: University of Nebraska Press, 1990. Print.

Journal Papers:

[26] Butler, Judith. Gender Trouble. New York: Routledge, 1990. Print. Butler, Judith. "Performative Acts and Gender Constitution: An Essay in Phenomenology and Feminist Theory" Theatre Journal 40.4(1988): 519-531. Print.

Journal Papers:

[27] Crary, Alice. “The Happy Truth: J.L. Austin's How to Do Things with Words” Inquiry 45 (2002): 37-59. Print.

Books:

[28] Baker,Sheriden. Earnest Hemingway: An Introduction and Interpretation. New York: Holt, Rinehart and Winston, 1967. Print.

Books:

[29] Donaldson, Scott. The Cambridge Companion to Ernest Hemingway. Australia: CUP, 1998. Print.

Books:

[30] Booker, M. Keith. A Practical Introduction to Literary Theory and Criticism. New York: White Plains, 1996. Print.

E-Books:

[31] Kobler. J.F. "Ernest Hemingway: Journalist and Artist" Rev. of Gerry Brenner, by Mark Busby. South Central Review, 1987. http://www.jstor.org/stable/3189176. 8 April. 2011.

Journal Papers:

[32] Herndll, Diane Price. "Invalid Masculinity: Silence, Hospitals, and Anesthesia in A Farewell to Arms" Hemingway Review 21 (2001): 38-52. Print.

Journal Papers:

[33] Wilhelm, Randall S. "Objects on the Table: Anxiety And Still Life in Hemingway's A Farewell to Arms" The Hemingway Review 26.1 (2006): 63-80. Print.

Books:

[34] Lynn, Kenneth S. Hemingway. New York: Ballantyne, 1987. Print. 